\title{
Antibiosis and antixenosis resistance to oviposition by Bemisia tabaci (Gennadius) B biotype (Hemiptera: Aleyrodidae) in soybean genotypes
}

\author{
Antibiose e antixenose para oviposição da Bemisia tabaci (Gennadius) \\ Biótipo B (Hemiptera: Aleyrodidae) em genótipos de soja
}

\author{
Vanusa Rodrigues Horas ${ }^{1 *}$, Paulo Eduardo Degrande', Carlos Eduardo Carducci ${ }^{1}$, \\ Marcos Gino Fernandes ${ }^{1}$
}

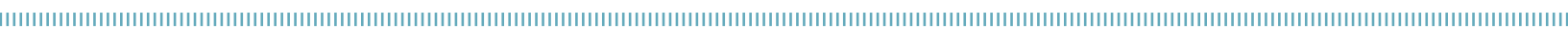

\begin{abstract}
This study was aimed at assessing some biological parameters of Bemisia tabaci B biotype at immature stages to examine antibiosis in six soybean genotypes, besides antixenosis resistance to oviposition in choice and non-choice tests, under greenhouse and laboratory conditions. Between April 2016 and August 2016, bioassays were carried out at the Laboratory of Applied Entomology at College of Agricultural Sciences at Federal University of Grande Dourados (UFGD) Dourados (MS), Brazil. The following variables were evaluated: egg incubation period, nymphal and egg-to-adult duration, egg and nymph viability, and egg-to-adult survival on the soybean genotypes 68i70 RSF IPRO, M6210 IPRO, MS 947 IPRO, BMX Potência RR, M6410 IPRO, and ANTA 82 RR. Antixenosis resistance to oviposition by the silverleaf whitefly was found for MS 947 IPRO, while oviposition was highest for ANTA 82 RR, M6210 IPRO, and M6410 IPRO. The genotype MS 947 IPRO adversely affected egg and nymph viability, and egg-to-adult survival rates was the lowest among genotypes $(59.75 \%)$, suggesting antibiosis resistance to this pest.
\end{abstract}

KEYWORDS: host plant resistance; Glycine max L.; silverleaf whitefly; non preference.
RESUMO: Este trabalho teve por objetivo avaliar a antibiose em seis genótipos de soja da Bemisia tabaci biótipo B mediante alguns parâmetros biológicos das fases imaturas do inseto, assim como analisar a resistência do tipo antixenose para oviposição em testes com e sem chance de escolha, em laboratório e casa de vegetação. Os ensaios foram conduzidos no Laboratório de Entomologia Aplicada da Faculdade de Ciências Agrárias da Universidade Federal da Grande Dourados (UFGD), Dourados (MS), entre os meses de abril e agosto de 2016. As variáveis averiguadas foram: período de incubação dos ovos; período ninfal; duração de ovo a adulto; viabilidade de ovo; viabilidade de ninfa e sobrevivência de ovo a adulto. Os genótipos de soja avaliados foram: 68i70 RSF IPRO, M6210 IPRO, MS 947 IPRO, BMX Potência RR, M6410 IPRO e ANTA 82 RR. O genótipo que apresentou antixenose para oviposição da mosca-branca foi o MS 947 IPRO, e constatou-se que o maior número de postura foi realizado nos genótipos ANTA 82 RR, M6210 IPRO e M6410 IPRO. O genótipo MS 947 IPRO também afetou negativamente a viabilidade de ovos e ninfas, bem como a sobrevivência de ovo a adulto, com as menores porcentagens de sobrevivência (59,75\%), indicando possível resistência do tipo antibiose à mosca-branca.

PALAVRAS-CHAVE: resistência de plantas; Glycine max L.; mosca-branca; não preferência. 


\section{INTRODUCTION}

The silverleaf whitefly, Bemisia tabaci $\mathrm{B}$ biotype, has become an important pest of soybeans, Glycine max (L.) Merrill (VIEIRA et al., 2011), and was reported in Brazil for the first time in the state of São Paulo in 1991 (LOURENÇÃO; NAGAI, 1994). Adults and nymphs constantly feed on phloem, inject toxins, and excrete honeydew on leaves, promoting the growth of sooty mold (Capnodium sp.), which reduces photosynthetic capacity and other physiological functions of the plant (MUSA; REN, 2005; NARANJO; LEGG, 2010; CAMERON et al., 2013).

In severely-infested plants, wilting and premature defoliation are observed, anticipating the crop cycle (HOROWITZ et al., 2011). Also, B. tabaci B biotype is associated with the transmission of the cowpea mild mottle virus (CPMMV) (MARUBAYASHI et al., 2010; POLSTON et al., 2014), which can decrease yields.

Conventional chemical control is the most often method used for the silverleaf whitefly, despite its resistance to many classes of conventional insecticides (HOROWITZ; ISHAAYA, 1995; SILVA et al., 2009). Given the environmental effects of pesticides and pest resistance, alternative and less aggressive control methods are needed.

Among alternative measures, a promising approach is the characterization of soybean genotypes resistant to $B$. tabaci $\mathrm{B}$ biotype and that can assist breeding programs in the selection of less susceptible cultivars. This approach has been increasingly used in part because of its potential and its compatibility with other integrated pest management (IPM) strategies. In this context, several soybean genotypes have been characterized for whitefly resistance, especially for $B$. tabaci $B$ biotype (VIEIRA et al., 2011; SILVA et al., 2012; CRUZ et al., 2016).

Plant resistance to insect attack can be expressed through antibiosis, which can directly influence insect biology, impairing its development, reproduction, survival among other biological parameters, and indirectly (antixenosis), adversely affecting insect behavior during the process of colonization, or the plant may be tolerant and not influence insect behavior or biology (PAINTER, 1951).

In Brazil, several studies have been carried out to select B. tabaci B biotype resistant soybean genotypes (Table 1). In general, most studies have focused on antixenosis and antibiosis (LIMA et al., 2002; LIMA; LARA, 2004), but no studies have investigated tolerance. Among the genotypes characterized as resistant to B. tabaci, IAC-17, IAC-19 and IAC-24 developed by Instituto Agronômico de Campinas (IAC) were the most prominent ones (VALLE; LOURENÇÃO, 2002; VALLE et al., 2012).

In some resistance assays, antixenosis and antibiosis often overlap, such as in the genotypes P98Y11, UX-2569-159,

Table 1. Soybean genotypes evaluated regarding resistance types to Bemisia tabaci biotype B.

\begin{tabular}{|c|c|c|}
\hline Genotypes & Types of Resistance & Reference \\
\hline IAC 74-2832 & Antixenosis & LIMA et al., 2002 \\
\hline D 75-10169 & Antixenosis & VALLE; LOURENÇÃO, 2002 \\
\hline Coodetec 201 & Antixenosis & VALLE; LOURENÇÃO, 2002 \\
\hline BR-82 12547 & Antixenosis & LIMA et al., 2002; LIMA; LARA, 2004 \\
\hline IAC- 100 & Antibiosis & LIMA; LARA, 2004 \\
\hline BABR $01-1576$ & Antibiosis & VIEIRA et al., 2011 \\
\hline BABR 99-4021 HC & Antibiosis & VIEIRA et al., 2011 \\
\hline Barreiras & Antixenosis & VIEIRA et al., 2011 \\
\hline IAC-PL1 & Antibiosis & SILVA et al., 2012 \\
\hline IAC-24 & Antibiosis & SILVA et al., 2012 \\
\hline Conquista & Antixenosis & SILVA et al., 2012 \\
\hline TMG 132 RR & Antibiosis/ Antixenosis & CRUZ; BALDIN, 2016 \\
\hline KS-4202 & Antixenosis & CRUZ et al., 2016 \\
\hline IAC-17 & Antibiosis/Antixenosis & VALLE; LOURENÇÃO, 2002; SILVA et al., 2012; BALDIN et al., 2017 \\
\hline IAC-19 & Antibiosis/ Antixenosis & VALLE; LOURENÇÃO, 2002; SILVA et al., 2012; BALDIN et al., 2017 \\
\hline UX-2569-159 & Antibiosis/ Antixenosis & CRUZ; BALDIN, 2016; BALDIN, 2017 \\
\hline PI 229358 & Antixenosis & LIMA; LARA, 2004; BALDIN et al., 2017 \\
\hline P98Y 11 & Antibiosis/ Antixenosis & CRUZ; BALDIN, 2016; BALDIN et al., 2017 \\
\hline Jackson & Antixenosis & BALDIN et al., 2017 \\
\hline TMG1 176 RR & Antixenosis & BALDIN et al., 2017 \\
\hline
\end{tabular}


IAC-17, IAC-19, and TMG132 RR (VALLE; LOURENÇÃO, 2002; SILVA et al., 2012; CRUZ; BALDIN, 2016; BALDIN et al., 2017), indicating that these plants express different genes, although the same gene can have more than one effect (LARA, 1991).

These studies indicate that soybean genotypes with characteristics of resistance can contribute to a better understanding of this approach, especially in the selection of the most promising genotypes to control $B$. tabaci $\mathrm{B}$ biotype.

This study was aimed at evaluating antibiosis resistance in different soybean genotypes to B. tabaci B biotype through some biological parameters of the immature phases of the insect, as well as to analyze antixenosis resistance to oviposition in choice and non-choice tests under laboratory and greenhouse conditions.

\section{MATERIALS AND METHODS}

The assays were conducted from April to August of 2016, in a greenhouse at the Laboratory of Applied Entomology of the Federal University of Grande Dourados (UFGD), Dourados (MS), Brazil. The treatments evaluated the most cultivated soybean genotypes in the state of Mato Grosso do Sul: 68i70 RSF IPRO, M6210 IPRO, MS 947 IPRO, BMX Potência RR, M6410 IPRO, and ANTA 82 RR. Seeds were sowed in 10-L plastic containers with a mixture of soil (dystroferric red latosol, from B horizon), coarse sand and substrate in a ratio of 1:1:1. The mixture was amended (FH 444 02-16-06 + micronutrients), and the $\mathrm{pH}$ was corrected as recommended by soil analysis.

\section{Silverleaf whitefly rearing}

The silverleaf whitefly population was identified by polymerase chain reaction (PCR) as B. tabaci $\mathrm{B}$ biotype, and mass reared in a greenhouse consisted of a metallic structure $(4 \times 6 \mathrm{~m})$, anti-aphid screen, and polycarbonate covering, to allow light for growing the host plant, collard greens (Brassica oleracea L. var. acephala), on which the insects were reared.

\section{Non-preference tests for oviposition: antixenosis}

The choice test consisted of six treatments (genotypes) and six replicates in a randomized block design. Each three blocks were comprised of a wooden cage ( $2 \mathrm{~m}$ long $\times 1.5 \mathrm{~m}$ wide $\times 2 \mathrm{~m}$ high) covered with anti-aphid screen. Thinning was carried out 10 days after emergence (d.a.e.) of plants, and two plants were left per pot.

A collard plant heavily infested with adults of $B$. tabaci $B$ biotype was placed in the center of each block, in an arena system, equidistant from the pots containing the six soybean genotypes in the $\mathrm{V} 3$ vegetative stage according to the FEHR; CAVINESS' (1977) scale. The number of eggs was evaluated 48 and $120 \mathrm{~h}$ after infestation. Three fully expanded upper leaflets were collected from each of the two soybean plants of each pot and taken to the laboratory, where the number of eggs on the abaxial surface of a leaf disc of $5.72 \mathrm{~cm}^{2}$ was counted with aid of a stereomicroscope.

For the non-choice test, the six genotypes with four replicates each were arranged using a completely randomized design. The genotypes were individually maintained since sowing in a cage $(45 \times 45 \times 55 \mathrm{~cm})$ protected with anti-aphid screen (Lab Creation). Thinning was carried out, leaving two plants per pot. When the plants reached the V3 vegetative stage, each cage was infested with approximately 300 unsexed whitefly adults from the rearing colony, with an entomological aspirator. The number of eggs was evaluated at 48 and $120 \mathrm{~h}$ after infestation, as described for the choice test.

\section{Antibiosis test}

The bioassay was carried out under greenhouse conditions, and the six genotypes were evaluated with a completely randomized design and five replicates. This assay followed the procedures used in the non-choice test, except for: only one plant per pot was left after thinning, and the infestation in each cage consisted of approximately 200 adults of B. tabaci B biotype for $24 \mathrm{~h}$, after which adults were removed. With the aid of a pocket magnifying glass, eggs were counted and marked with a Pilot pen; excess eggs were removed from the leaf with a brush. Two groups of eggs were labeled, each contained 40 eggs in two random leaflets. The development of whiteflies was monitored daily, and newly emerged nymphs and adults were counted. The following biological parameters were determined: egg incubation period, nymphal period, egg-to-adult duration, egg viability, nymph viability, and egg-to-adult survival.

The temperature and relative humidity $(\mathrm{RH})$ of the greenhouse were recorded throughout the antibiosis assay with a thermohygrometer. The mean temperature recorded was $25.8^{\circ} \mathrm{C}$, with maximum of $37.0^{\circ} \mathrm{C}$, and minimum of $24.1^{\circ} \mathrm{C}$, while the mean $\mathrm{RH}$ was $59.9 \%$, with maximum of $64.4 \%$ and minimum of $55.3 \%$.

\section{Statistical analysis}

All analyses were performed using statistical software R, version 3.4.1 (R DEVELOPMENT CORE TEAM, 2017). Generalized linear models were used to study the effect of the soybean varieties on $B$. tabaci $\mathrm{B}$ biotype infestation. However, Poisson, quasi-binomial or binomial-negative models did not fit the data. The assumptions of the analysis of variance (ANOVA) were examined, and tests for homogeneity of 
variance (Barlett and Levene) were performed with the car package, while normality (Kolmogorov-Smirnov and ShapiroWilk test) was tested with the nortest package (Barlett and Levene). The assumptions of normality and homogeneity of variances were not met even when transforming the infestation variable with the Box-Cox method. Thus, the non-parametric Friedman test was used to analyze the choice assay. In the non-choice test, the non-parametric Kruskal-Wallis post-hoc test - Bonferroni method — was applied.

Requirements of normality and homogeneity of variance were also not met for the variables: duration of egg, nymph and egg/adult stages, and longevity of adults of B. tabaci B biotype. Therefore, the data was transformed using the Box-Cox function of the mass package. Lambda values that maximized the function were extracted and substituted in the formula: $y \mathrm{~T}=\mathrm{y} \lambda-1 / \lambda$ (BOX-COX, 1964). These data were examined with an analysis of variance, and the means were compared with the Tukey test $(P=0.05)$. A generalized linear model (GLM) (NELDER; WEDDERBURN, 1972) with quasi-binomial distribution was used to analyze egg and nymph viability and egg-to-adult survival. The quality of the adjustment was evaluated with a half-normal probability plots with simulation envelope using the hnp package (DEMÉTRIO et al., 2014).

All variables mentioned before were included to examine the level of similarity among genotypes. For this, a cluster was constructed using the Jaccard distance among the observations. The cluster analysis was conducted with the vegan package.

\section{RESULTS AND DISCUSSION}

In the choice test, based on the mean number of eggs laid by B. tabaci B biotype on a leaf disc of $5.72 \mathrm{~cm}^{2}$ of the abaxial surface of the upper leaflets in the $\mathrm{V} 3$ vegetative stage (Table 2), the least preferred genotype for whitefly oviposition at $48 \mathrm{~h}$ after infestation was BMX Potência RR (18.9 eggs), significantly lower than the means obtained for MS947 IPRO and M6210 IPRO (32.4 eggs and 30.9 eggs), which had the highest number of eggs. At $120 \mathrm{~h}$ after infestation, changes in the oviposition behavior of whiteflies were observed. The least preferred genotype for oviposition was MS947 IPRO (152.7 eggs), and the most preferred, ANTA 82 RR (301.6 eggs). According to LARA (1991), oviposition behavior may vary depending on the option of different hosts as a result of stimuli provided or produced by plants. According to MEINERS; HILKER $(2000,2002)$, plants may show direct defensive responses to egg laying, inducing the release of local and systemic defense volatiles in order to prevent new ovipositions.

The analysis of the interaction between genotypes and two evaluation periods of 48 and $120 \mathrm{~h}$ revealed significant differences (Table 2), indicating that, when given more time, whiteflies show preferences for oviposition.

In the non-choice test, based on the evaluations carried out at $48 \mathrm{~h}$ after infestation, mean oviposition differed among genotypes. M6210 IPRO (32.5), BMX Potência RR (36.3), M6410 IPRO (36.4), and MS947 IPRO (40.9) were the least preferred genotypes, while ANTA 82 RR (56.6) was the most preferred for oviposition (Table 3).

At $120 \mathrm{~h}$ of evaluation, the genotype ANTA 82 RR (187.8) had the highest mean number of whitefly eggs, unlike MS947 IPRO (75.5), that had the lowest number of eggs. This corroborated the results obtained with the choice test at $120 \mathrm{~h}$ after infestation.

For both periods evaluated, the genotype ANTA 82 RR also had the highest number of whitefly eggs, indicating that certain cultivars are more preferred than others for oviposition. In the comparison of the two evaluation periods of 48 and $120 \mathrm{~h}$, genotypes significantly differ, confirming the results found in the choice test.

In the assessment of the biological parameters of $B$. tabaci B biotype, the mean duration of egg incubation in soybean cultivars ranged from $8.9 \pm 0.04$ to $9.9 \pm 0.14$ days. Incubation was significantly shorter for eggs laid on MS947 IPRO than on the other genotypes (Table 4). Comparatively,

Table 2. Number (mean \pm standard error) of eggs of Bemisia tabaci B biotype on six soybean genotypes, in two periods after infestation in choice tests, Dourados (MS), Brazil, 2016.

\begin{tabular}{lcc} 
Genotypes & \multicolumn{2}{c}{ Eggs/5.72 $\mathbf{~ c m}^{2}$} \\
\cline { 2 - 3 } MS947 IPRO & 48 hours & 120 hours \\
\hline M6210 IPRO & $32.4 \pm 4.31 \mathrm{~A} b$ & $152.7 \pm 13.52 \mathrm{C} a$ \\
\hline M6410 IPRO & $30.9 \pm 2.29 \mathrm{AB} b$ & $254.9 \pm 30.30 \mathrm{AB} a$ \\
\hline BMX Potência RR & $23.9 \pm 2.97 \mathrm{ABC} b$ & $162.3 \pm 12.52 \mathrm{BC} a$ \\
\hline ANTA 82 RR & $18.8 \pm 3.29 \mathrm{C} b$ & $205.6 \pm 15.20 \mathrm{AB} a$ \\
\hline 68i70RSF IPRO & $25.5 \pm 3.07 \mathrm{BC} b$ & $301.6 \pm 26.22 \mathrm{~A} a$ \\
\hline
\end{tabular}

Means followed by same uppercase letters (within columns) and lowercase letters (within lines) are not significantly different based on the nonparametric Friedman test $\left(\chi^{2}=54.52 ; p<0.00001 ; F=23.75\right.$; least-significance difference - LSD $\left.=11.42\right)$; SE: standard error. 
LIMA; LARA (2004) observed a mean incubation period of 6.4 to 6.6 days in soybean genotypes.

The nymphal period ranged from 17.7 to 18.1 days on average, with the longest mean development time on the cultivar ANTA 82 RR and the shortest on MS947 IPRO. CRUZ; BALDIN (2016) reported a nymphal period in soybean genotypes ranging from 14.1 to 15.2 days.

Regarding egg-to-adult development, duration varied between 26.5 and 27.6 days, with the shortest mean observed for MS947 IPRO, significantly different from the genotype M6210 IPRO, with the longest duration. SILVA et al. (2012) obtained mean duration of 19.3 to 21.3 days for egg/adult period of whiteflies in soybean genotypes, while CRUZ; BALDIN (2016) reported duration of 22.7 and 24.2 days for different genotypes of soybean under greenhouse conditions.

The viability of whitefly eggs was adversely affected by MS947 IPRO, with the lowest mean of 70.7\%, differing significantly from the genotypes IPRO, ANTA 82 RR, M6210 IPRO, BMX RR, and M6410 IPRO, with viability rates of 92, 92, 93, 95 and 98\%, respectively (Fig. 1).
For nymphal viability, differences were observed among genotypes; the lowest mean was obtained for MS947 IPRO, ANTA 82 RR, and M6210 IPRO (67.8, 69.3 and 71.0\%), unlike IP64 M6410 (85.6\%), with the highest viability rate. SILVA et al. (2012), however, did not find significant differences in viability of whiteflies depending on soybean genotype, ranging from 74.7 to $88.8 \%$.

The egg-adult survival rate differed among soybean genotypes, with M6410 IPRO with the highest rate (83.7\%) and

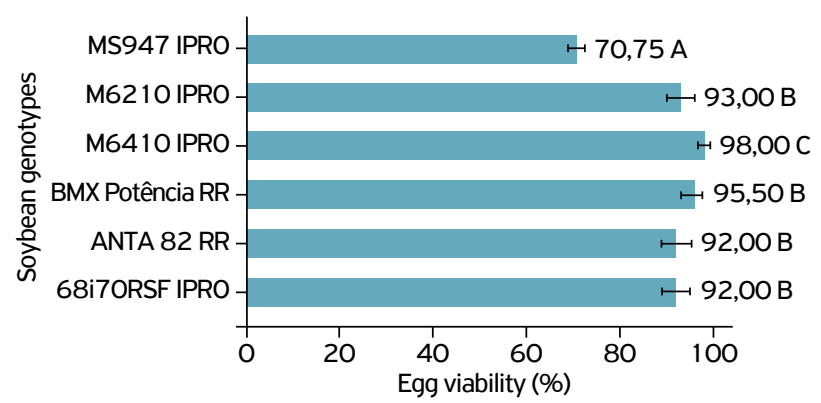

Figure 1. Egg viability (\%) of Bemisia tabaci B biotype on soybean genotypes, Dourados (MS), Brazil, 2016.

Table 3. Number (mean \pm standard error) of eggs of Bemisia tabaci B biotype on six soybean genotypes, in two periods after infestation in non-choice tests, Dourados (MS), Brazil, 2016.

\begin{tabular}{|c|c|c|}
\hline \multirow{2}{*}{ Genotypes } & \multicolumn{2}{|c|}{ Eggs $/ 5.72 \mathrm{~cm}^{2}$} \\
\hline & 48 hours & 120 hours \\
\hline MS947 IPRO & $40.9 \pm 8.48 \mathrm{~A} b$ & $75.5 \pm 7.76 \operatorname{CDE} a$ \\
\hline M62 10 IPRO & $32.5 \pm 5.19 \mathrm{~A} b$ & $182.6 \pm 21.94 \mathrm{AB} a$ \\
\hline M6410 IPRO & $36.4 \pm 5.54 \mathrm{~A} b$ & $98.4 \pm 16.26 \mathrm{CD} a$ \\
\hline BMX Potência RR & $36.3 \pm 7.86 \mathrm{~A} b$ & $152.8 \pm 19.66 \mathrm{ABC} a$ \\
\hline ANTA 82 RR & $56.6 \pm 10.36 \mathrm{~B} b$ & $187.8 \pm 14.08 \mathrm{~A} a$ \\
\hline 68i70RSF IPRO & $46.5 \pm 12.79$ АВ $b$ & $95.5 \pm 10.83 \mathrm{BCD} a$ \\
\hline
\end{tabular}

Means followed by same uppercase letters (within columns) and lowercase letters (within lines) are not significantly different based on the non-parametric Kruskal-Wallis post-hoc test — Bonferroni correction; t-Student: 3.405883; alpha: 0.05; least-significance difference — LSD: 61.16035; SE: standard error.

Table 4. Mean incubation period, nymphal period, egg-to-adult duration, nymphal viability, and egg-to-adult survival rate (mean \pm standard error) of Bemisia tabaci B biotype obtained in six soybean genotypes under greenhouse conditions, Dourados (MS), Brazil, 2016.

\begin{tabular}{lccccc} 
Genotypes & $\begin{array}{c}\text { Incubation } \\
\text { period (days) }\end{array}$ & $\begin{array}{c}\text { Nymphal } \\
\text { period (days) }\end{array}$ & $\begin{array}{c}\text { Egg/adult } \\
\text { duration (days) }\end{array}$ & $\begin{array}{c}\text { Nymphal } \\
\text { viability (\%) }\end{array}$ & $\begin{array}{c}\text { Egg/adult } \\
\text { survival rate (\%) }\end{array}$ \\
\hline MS947 IPRO & $8.9 \pm 0.04 \mathrm{a}$ & $17.7 \pm 0.04 \mathrm{a}$ & $26.5 \pm 0.05 \mathrm{a}$ & $67.8 \pm 4.96 \mathrm{a}$ & $59.7 \pm 1.14 \mathrm{a}$ \\
\hline M6210 IPRO & $9.9 \pm 0.14 \mathrm{~b}$ & $18.0 \pm 0.04 \mathrm{ab}$ & $27.6 \pm 0.18 \mathrm{~b}$ & $71.0 \pm 4.55 \mathrm{a}$ & $65.2 \pm 3.21 \mathrm{a}$ \\
\hline M6410 IPRO & $9.5 \pm 0.05 \mathrm{~b}$ & $17.9 \pm 0.03 \mathrm{a}$ & $27.2 \pm 0.03 \mathrm{c}$ & $85.6 \pm 3.10 \mathrm{~b}$ & $83.7 \pm 2.84 \mathrm{~b}$ \\
\hline BMX Potência RR & $9.3 \pm 0.05 \mathrm{~b}$ & $17.8 \pm 0.04 \mathrm{a}$ & $26.8 \pm 0.04 \mathrm{ad}$ & $84.7 \pm 1.66 \mathrm{ab}$ & $65.5 \pm 5.77 \mathrm{a}$ \\
\hline ANTA 82 RR & $9.4 \pm 0.06 \mathrm{~b}$ & $18.1 \pm 0.04 \mathrm{~b}$ & $27.1 \pm 0.05 \mathrm{~cd}$ & $69.3 \pm 4.60 \mathrm{a}$ & $63.5 \pm 4.25 \mathrm{a}$ \\
\hline 68i70RSF IPRO & $9.3 \pm 0.05 \mathrm{~b}$ & $18.1 \pm 0.02 \mathrm{~b}$ & $27.0 \pm 0.05 \mathrm{~cd}$ & $73.7 \pm 4.33 \mathrm{ab}$ & $67.7 \pm 4.57 \mathrm{ab}$ \\
\hline F & 14.16 & 11.79 & 04.83 & 7.85 & 03.89 \\
\hline CV (\%) & 05.69 & 0.25 & 18.32 & 9.03 & 16.93 \\
\hline
\end{tabular}

'Means followed by same letters (within columns) are not significantly different based on the Tukey test ( $p=0.05) ;{ }^{2}$ means followed by same letters (within columns) are not significantly different based on the overlap of confidence intervals (CI95\%) generated by generalized linear models with quasi-binomial distribution; SE: standard error. 
the genotypes MS947 IPRO, ANTA 82 RR, M6210 IPRO and BMX Potência RR with the lowest percentages (59.7, 63.5, 65.2 and 65,5\%).

Regarding the groups in the dendrogram from the base to the top, a high similarity was observed between the genotypes M6210 IPRO and ANTA 82 RR in the first group and 68i70RSF IPRO and M6410 IPRO in the second group. Within the first and second groups, dissimilarity was greater for BMX Potência RR and MS947 IPRO, respectively (Fig. 2).

A possible resistance mechanism due to non-preference for oviposition and/or antibiosis of the genotype MS947 IPRO may explain this dissimilar behavior of whiteflies compared

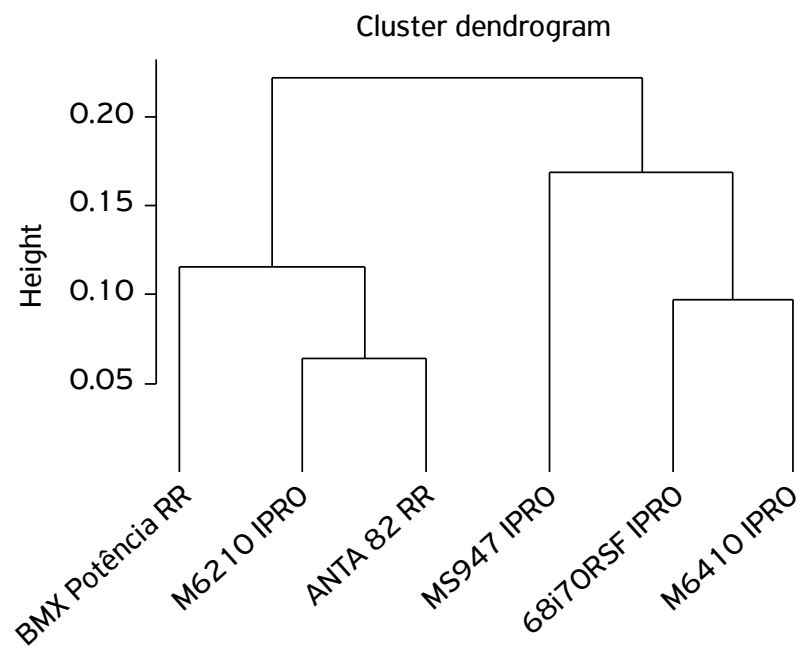

Figure 2. Average linkage clustering of soybean varieties based on the variables associated to infestation, survival, and development duration, and longevity of Bemisia tabaci. to other genotypes, as suggested by the lowest mean oviposition rates and adverse effects on egg viability, nymph and egg-to-adult survival rates of $B$. tabaci $\mathrm{B}$ biotype, as well as the shortest developmental period. The genotypes ANTA 82 RR and M6410 IPRO were the most susceptible to whitefly, with the highest means of oviposition and better viability of eggs, nymphs, and survival.

\section{CONCLUSIONS}

Among the soybean genotypes tested, MS947 IPRO showed non-preference resistance to oviposition by B. tabaci B biotype, in addition to negatively affect the viability of eggs, nymphs, and egg-to-adult survival of whitefly, characterizing antibiosis. The genotypes ANTA 82 RR, IPRO M6210 and IPRO M6410 were the most susceptible to B. tabaci biotype.

\section{ACKNOWLEDGMENTS}

The authors thank the Foundation for the Support to the Development of Education, Science and Technology of the state of Mato Grosso do Sul (FUNDECT) / Brazilian National Council for Scientific and Technological Development (CNPq), for granting the Regional Scientific Development Fellowship (Desenvolvimento Científico Regional - DCR) to the first author (Process no. 23/200.740/2014), José Bruno Malaquias (Luiz de Queiroz College of Agriculture — ESALQ / University of São Paulo — USP), for statistical support; and Dr. Eduardo Neves Costa, for contributions and suggestions.

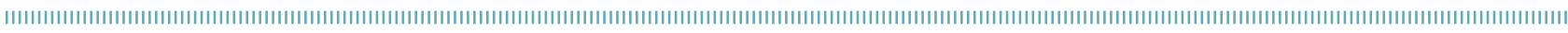
REFERENCES

BALDIN, E.L.L.; CRUZ, P.L.; MORANDO, R.; SILVA, I.F.; BENTIVENHA, J.P.F.; TOZIN, L.R.S.; RODRIGUES, T.M. Characterization of Antixenosis in Soybean Genotypes to Bemisia tabaci (Hemiptera: Aleyrodidae) B biotype. Journal of Economic Entomology, v. 1 10, n.4, p. 1869-1876, 2017. doi: 10.1093/jee/tox 143

BOX, G.E.P.; COX, D.R. An analysis of transformations. Journal of the Royal Society, v.26, n.2, p.211-252, 1964. ttp://www. jstor.org/stable/2984418

CAMERON, R.; LANG, E.B.; ANNAN, I.B.; PORTILLO, H.E.; ALVAREZ, $J$. M. Use of fluorescence, a novel technique to determine reduction in Bemisia tabaci (Hemiptera: Aleyrodidae) nymph feeding when exposed to benevia and other insecticides. Journal of Economic Entomology, v.106, n.2, p.597-603, 2013. https:// doi.org/10.1603/EC12370

CRUZ, P.L.; BALDIN, E.L.L.; GUIMARÃES, L.R.P.; PANNUTI, L.E.R.; LIMA, G.P.P.; HENG-MOSS, T.; HUNT, T.E. Tolerance of KS-4202 soybean to the attack of Bemisia tabaci B biotype (Hemiptera: Aleyrodidae). Florida Entomologist, v.99, n.4, p.600-607, 2016. https://doi.org/10.1653/024.099.0403

.; Performance of Bemisia tabaci B biotype on Soybean Genotypes. Neotropical Entomology, v.46, n.2, p.210215, 2016. doi: 10.1007/s13744-016-0445-3 
DEMÉTRIO, C.G.B.; HINDE, J.; MORAL, R.A. Models for Overdispersed Data in Entomology. In: FERREIRA, C.; GODOY, W. (Eds.). Ecological Modelling Applied to Entomology. Entomology in Focus, 2014. p.262.

FEHR, W.R.; CAVINESS, C.E. Stages of soybean development. lowa State University Cooperative Extension Service. Special Report, v.80, p. 1-12, 1977.

FERREIRA, C.P.; GODOY, W.A.C. Models for overdispersed data in entomology. Ecological Modelling Applied to Entomology, v.1, p. 219-259, 2014.

HOROWITZ, A.R.; ANTIGNUS, Y.; GERLING, D. Management of Bemisia tabaci WHITEFLIES. In: THOMPSON, W.M.O. (Ed.). The Whitefly, Bemisia tabaci (Homoptera: Aleyrodidae) Interaction with Geminivirus-Infected Host Plants. Dordrecht: Springer, 2011 . p. 293-232.

.; ISHAAYA, I. Chemical control of Bemisia-management and application. In: GERLING, D.; MAYER, R.T. (Ed.). Bemisia 1995: taxonomy, biology, damage control and management. Andover: Intercept Ltd., 1995. p. 537-556.

LARA, F.M. Princípios de resistência de plantas a insetos. 2 . ed. São Paulo: Ícone, 1991. 336p.

LIMA, A.C.S.; LARA, F.M. Resistência de genótipos de soja à moscabranca Bemisia tabaci (Genn.) biótipo B (Hemiptera: Aleyrodidae). Neotropical Entomology, v.33, n. 1, p.71-75, 2004. http://dx.doi. org/10.1590/S1519-566X2004000100013

; BARBOSA, J.C. Preferência para oviposição de Bemisia tabaci biótipo B (Hemiptera: Aleyrodidae) em genótipos de soja, sob condições de campo. Neotropical Entomology, v.31, n.2, p.297-303, 2002. http://dx.doi.org/10.1590/ S1519-566X2002000200018

LOURENÇÃO, A.L.; NAGAI, H. Surtos populacionais de Bemisia tabaci no estado de São Paulo. Bragantia, Campinas, v.53, n. 1, p.53-59, 1994. http://dx.doi.org/10.1590/ S0006-87051994000100006

MARUBAYASHI, J.M.; YUKI, V.A.; WUTKE, E.B. Transmissão do Cowpea mild mottle virus pela mosca branca Bemisia tabaci biotipo B para plantas de feijão e soja. Summa Phytopathol, Botucatu, v.36, n.2, p.158-160, 2010. http://dx.doi.org/10.1590/ so $100-54052010000200009$

MEINERS, T.; HILKER, M. Induction of plant synomones by oviposition of a phytophagous insect. Journal of Chemical Ecology, v.26, n.1, p.221-232, 2000. https://doi. org/10.1023/A: 1005453830961

.;___ Induction of plant responses to oviposition and feeding by herbivorous arthropods: a comparison. Entomologia
Experimentalis et Applicata, v.104, n.1, p.181-192, 2002. doi: 10.1046/j.1570-7458.2002.01005.x

MUSA, P.D.; REN, R. Development and reproduction of Bemisia tabaci (Homoptera: Aleyrodidae) on three bean species. Insect Science, v.12, n.1, p.25-30, 2005. https://doi. org/10.1111/j.1672-9609.2005.00004.x

NARANJO, S.E.; LEGG, J.P. Biology and ecology of Bemisia tabaci. In: STANSLY, P.A.; NARANJO S.E. (Ed.). Bemisia: bionomics and management of a global pest. Dordrecht: Springer, 2010.

NELDER, J.A.E.; WEDDERBURN, R.W.M. Generalized linear models. Journal of the Royal Statistical Society, v. 135, n.3, p.370-384, 1972.

PAINTER, R.H. Insect resistance in crop plants. New York: McMillan, 1951. 520p.

POLSTON, J.E.; DE BARRO, P.; BOYKIN. L.M. Transmission specificities of plant viruses with the newly identified species of the Bemisia tabaci species complex. Pest Management Science, v.70, n.10, p.1547-1552, 2014. https://doi.org/10.1002/ps.3738

R DEVELOPMENT CORE TEAM. R: A Language and Environment for Statistical Computing. Vienna, Austria: the R Foundation for Statistical Computing. 2017. Disponível em: <http://www.Rproject.org/>. Access on: 20 Oct. 2017.

SILVA, J.P.G.F.; BALDIN, E.L.L.; SOUZA, E.S.; LOURENÇÃO, A.L. Assessing Bemisia tabaci (Genn.) B biotype resistance in soybean genotypes: antixenosis and antibiosis. Chilean Journal of Agricultural Research, v.72, n.4, p.516-522, 2012.

SILVA, L.D.; OMOTO, C.; BLEICHER, E.; DOURADO, P. M. Monitoramento da suscetibilidade a inseticidas em populações de Bemisia tabaci (Gennadius) (Hemiptera: Aleyrodidae) no Brasil. Neotropical Entomology, Londrina, v.38, n.1, p.116-25, 2009. http://dx.doi.org/10.1590/S1519-566X2009000100013

VALLE, G.E.; LOURENÇÃO, A.L. Resistência de genótipos de soja a Bemisia tabaci (Genn.) biótipo B (Hemiptera: Aleyrodidae). Neotropical Entomology, v.31, n.2, p.285-295, 2002. http://dx.doi.org/10.1590/ S1519-566X2002000200017

; PINHEIRO, J.B. Adult attractiveness and oviposition preference of Bemisia tabaci $\mathrm{B}$ biotype in soybean genotypes with different trichome density. Journal of Pest Science, v.85, n.4, p.431-442, 2012. https://doi.org/10.1007/ s10340-012-0443-0

VIEIRA, S.S.; BUENO, A.F.; BOFF, M.I.C.; BUENO, R.C.O.F.; HOFFMAN-CAMPO, C.B. Resistance of soybean genotypes to Bemisia tabaci (Genn.) B biotype (Hemiptera: Aleyrodidae). Neotropical Entomology, v.40, n.1, p.117-122, 2011. http:// dx.doi.org/10.1590/S1519-566X2011000100018 